\title{
A Tribute to Professor Ryszard Kryza (1950-2015)
}

\section{Marek Awdankiewicz*}

*University of Wrocław; Institute of Geological Sciences; Department of Mineralogy and Petrology; pl. M. Borna 9; 50-204 Wrocław, Poland

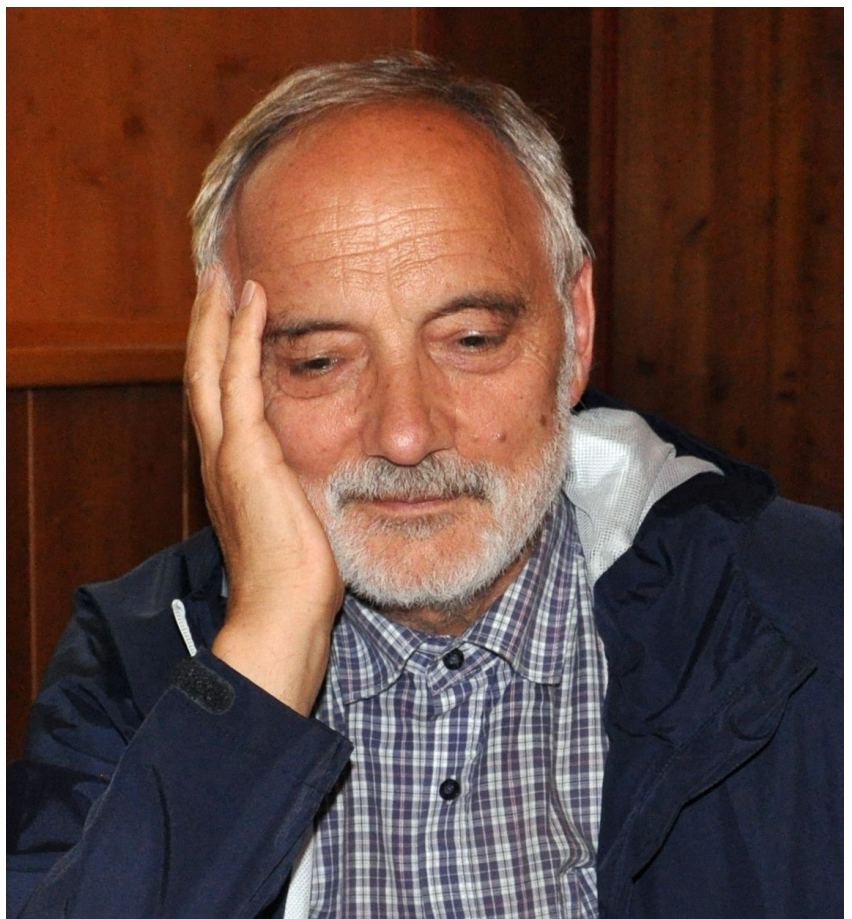

Professor Ryszard Kryza was a wonderful man and a great geologist, an authority in several everyday affairs and scientific problems. He kept commitments, met deadlines, kept his word and always had time for other people, students and co-workers. He managed to provide simple solutions to intricate problems and gave effective advice when faced with challenges. Ryszard Kryza was unusually diligent and never wasted a minute. Despite his great achievements in his professional career, he did not care much about honours. He was passionate about travelling, photography and music; he loved to be with people and to explore new, exotic tastes of the world. During the fight for democratic change in Poland, in the 1980s, as an active member of the 'Solidarity' movement, he was oppressed by the communist authorities, for example, they repeatedly refused to grant him a passport. Ryszard Kryza was deeply involved in various aspects of the organisation of academic science and teaching. Thanks to him, several tens of students and young aspiring geologists were able to initiate and develop international scientific contacts, which is so important for the present-day academic careers. For his co-workers and university colleagues, Ryszard Kryza created possibilities
On 25th December 2015, Professor Ryszard Kryza passed away. He had been fighting severe illness for the last few years. His family, friends and co-workers all hoped that Ryszard's will to live and the modern medicine, would win. Suddenly and sadly, the opposite happened.

for free scientific and organisational development. As a result of his work, he is placed among the most deserving and outstanding scientists of the University of Wrocław.

Ryszard Kryza was born on $13^{\text {th }}$ December 1950 at Wilczyce. He graduated in geology at the University of Wrocław in 1973, and defended his PhD thesis, supervised by Professor Alfred Majerowicz, on 'Migmatisation in gneisses and migmatites of the northern part of the Góry Sowie' in 1979. His habilitation, completed in 1994, was based on the dissertation 'The basic metavolcanic rocks of the central part of the Kaczawa Mts.' He was nominated for the scientific title of professor in 1999. The scientific career of Ryszard Kryza at the University of Wrocław began with the position of a technician (in 1972); later, he became an assistant, adjunct, associate professor, finally reaching the position of a professor (in 2006). From 1995, for 20 years, Ryszard Kryza was the head of the Department of Mineralogy and Petrology at the Institute of Geological Sciences.

The scientific interests and publications of Ryszard Kryza were focussed around the problems of petrology and geochemistry of igneous and metamorphic rocks. His achievements in these fields 
brought answers to several critical questions on magmatic and metamorphic rock complexes and evolution of the Variscan Orogen of Europe. A related group of issues included the application of accessory minerals, such as monazite or zircon, as indicators of origin and age of rocks. Other important topics in Ryszard Kryza's research were new minerals, meteorites, environmental hazards and protection, as well as stone in architecture.

Ryszard Kryza was a member of several international and national research groups; but it was him, in many cases, who initiated and led the projects and later coordinated the publication of results. He was a great authority in Earth sciences, of unusually broad scientific horizons. He was the author and co-author of over 400 scientific publications, largely in the most renowned scientific journals. He was one among the most cited Polish geologists. The distinctive features of the scientific studies carried out by Ryszard Kryza included the application of the methods of mineralogical sciences in various branches of Earth and environmental sciences, as well as the integration of basic field studies with advanced laboratory techniques. This approach, although not easy for practical application, turned out to be the key for successful investigation and reliable interpretation in complex geological and petrological issues. Among the many scientific achievements of Ryszard Kryza, the following can be considered the most important:

- Recognition of petrological and geochemical variation as the record of the evolving rifting processes in the Palaeozoic metavolcanogenic succession of the Kaczawa Complex (together with A. Muszyński and others);

- Documentation of the blueschist facies metamorphism in the Kaczawa Complex (together with A. Muszyński) and in the east cover of the Karkonosze pluton (together with S. Mazur);

- Determination of the sequence and P-T conditions of metamorphic events in gneisses, migmatites and granulites of the Góry Sowie Block and other geological units of the Sudetes;

- Determination of the magmatic age of Palaeozoic ophiolites and granitoid intrusions in Lower Silesia (together with T.Oberc-Dziedzic, C.Pin and others);

- Verification and proposals of new geotectonic models of the eastern part of the European Variscides (together with P. Aleksandrowski, S. Mazur, T. Oberc-Dziedzic, C. Pin, J. Zalasiewicz and others);

- Discovery of Proterozoic zircons in Mesozoic plagiogranites in the ophiolitic complexes of Dinarides in Albania (together with A. Beqiraj);

- Application and testing of chemical monazite dating method (in an international research team);

- Studies of meteorites, including the finding of keilite in the Zakłodzie meteorite and the discovery of two new minerals (moraskoite and czochralskiite) in the Morasko meteorite (together with $Ł$. Karwowski, A. Muszynski, T. Przylibski and others) and
- Numerous studies of stone materials in the monuments of architecture and art in Wrocław, Vilnius, St. Petersburg and other places, and studies of deterioration of stone materials in polluted air conditions.

The results of these studies were published in several papers, including the most highly cited ones which are as follows:

- $\quad$ Aleksandrowski P., Kryza R., Mazur S., Żaba J., 1997: Kinematic data on major Variscan strike-slip faults and shear zones in the Polish Sudetes, northeast Bohemian Massif. Geological Magazine, 134/5: 727-739.

- $\quad$ Furnes H., Kryza R., Muszyński A., Pin C., Garmann L.B., 1994: Geochemical evidence for progressive rift-related volcanism in the eastern Variscides. Journal of Geological Society of London, 151: 91-109.

- Kryza R., Crowley Q.G., Larionov A., Pin C., Oberc-Dziedzic T., Mochnacka K., 2012: Chemical abrasion applied to SHRIMP zircon geochronology: An example from the Variscan Karkonosze Granite (Sudetes, SW Poland). Gondwana Research, 21: 757-767.

- Kryza R., Muszyński A., Vielzeuf D., 1990: Glaucophane-bearing assemblage overprinted by greenschist-facies metamorphism in the Variscan Kaczawa complex, Sudetes, Poland. Journal of Metamorphic Geology, 8: 345-355.

- Kryza R., Pin C., 2010: The Central-Sudetic ophiolites (SW Poland): Petrogenetic issues, geochronology and palaeotectonic implications. Gondwana Research, 17/2-3: 292-305.

- Kryza R., Pin C., Vielzeuf D., 1996: High pressure granulites from the Sudetes (SW Poland): evidence of crustal subduction and collisional thickening in the Variscan Belt. J. Metamorphic Geology, 14/4: 531-546.

- Mazur S., Aleksandrowski P., Kryza R., Oberc-Dziedzic T., 2006: The Variscan Orogen in Poland. Geol. Quart., 50 (1): 89-118.

- O'Brien P.J., Kroener A., Jaeckel P., Hegner E., Żelaźniewicz A., Kryza R., 1997: Petrological and isotopic studies on highpressure granulites, Góry Sowie Mts, Polish Sudetes. Journal of Petrology, 38/4: 433-456.

- Oberc-Dziedzic T., Klimas K., Kryza R., Fanning C.M., 2003: SHRIMP zircon geochronology of the Strzelin gneiss, SW Poland: Neoproterozoic thermal event in the Fore-Sudetic Block, Central European Variscides. International Journal of Earth Sciences, 92: 701-711.

- The PACE TMR Network Team (Kryza R. included) and J.A. Winchester, 2002: Palaeozoic amalgamation of central Europe: new results from recent geological and geophysical investigations. Tectonophysics 360, 1-4: 5-21.

- $\quad$ Timmermann H., Parrish R.R., Noble S.R., Kryza R., 2000: New $\mathrm{U}-\mathrm{Pb}$ monazite and zircon data from the Sudetes Mountains in SW Poland: evidence for a single-cycle Variscan orogeny. J. Geol. Soc. London, 157: 265-268.

During his professional carrier, Professor Ryszard Kryza was deeply involved in teaching and organisation of scientific life at the University of Wrocław. Apart from being a lecturer, he was the 
promoter of approximately $40 \mathrm{MSc}$ and $11 \mathrm{PhD}$ theses in Geology and Environment Protection. He was the coordinator of new teaching programmes and the leader of specialisation in mineralogy and petrology in the field of Geology. He successfully organised laboratories such as the Microprobe Laboratory, Thin Section Laboratory and Mineral Separation Laboratory at the university. He led the scientific collaboration between the Wrocław University and several academic and research institutions abroad, including Universite B. Pascal, Clermont-Ferrand (France), RuhrUniversität Bochum (Germany), Oxford University (UK), University of Leicester (UK), University of Salzburg (Austria), GeoForschungsZentrum Potsdam (Germany), NHM Sztokholm (Sweden), Universite de Geneve (Switzerland), Universitat Frankfurt (Germany), VSEGEl St. Petersburg (Russia) and the Academy of Geological Sciences, Beijing (China). At the University of Wrocław, he also coordinated international research projects such as EUROPROBE, PACE, Rheic Ocean and others, and international academic exchange projects such as TEMPUS and CEEPUS. This multi-sided activity enabled Ryszard Kryza to carry out research at the highest level and, importantly, helped a large number of students and academic staff from the University of Wrocław to get fellowships and visit highly recognised scientific institutions in Europe. A significant part of this work also included the organisation and coorganisation of geological and mineralogical congresses, conferences and meetings.
Professor Ryszard Kryza was an active member of several professional organisations, societies and committees in mineralogy, petrology and geology. He was the President of the Mineralogical Society of Poland (2009-2012), a member of the Committee of Mineralogical Sciences of the Polish Academy of Science and, in recent years, a member of the Committee of Geological Sciences of the Polish Academy of Science and a member of the Polish Central Committee for Degrees and Titles. He was a member of the editorial boards of scientific journals and prepared many reviews of papers submitted to the high-impact scientific journals. He was also a reviewer of several PhD and habilitation dissertations and of applications on the title of professor.

Ryszard Kryza received many awards and decorations, including the Silver Student Decoriation 'Primus Inter Pares' (1972), MSc Diploma with Honours (1973), the Ignacy Domeyko Award of the Polish Academy of Science (1989), the individual award of the Ministry of National Education (1995), the Gold Cross of Merit (1998) and 28 awards of the Rector of the University of Wrocław for achievements in science and didactics. In autumn 2015, he was awarded the Gold Medal of the University of Wrocław. But sadly, he was not strong enough to accept this last honour personally. 